JUURNAL

of Health Inequalities

\title{
Letter to the Editors concerning the paper "Potential savings resulting from avoided hospitalizations and avoided productivity losses due to low influenza vaccination coverage in Poland"
}

\author{
Janusz Szymborski \\ The Government Population Council, Warsaw, Poland
}

ADDRESS FOR CORRESPONDENCE: Janusz Szymborski, The Government Population Council,

208 Aleja Niepodległości Str., 00-925 Warsaw, Poland, e-mail: janusz.szymborski@gmail.com

I am a doctor who appreciates the importance of protective vaccinations. The last epidemic of smallpox, the eradication of which was announced in 1980, coincided with the beginning of my studies at Wrocław Medical University. I was taught how beneficial vaccinations are, and I passed this knowledge on to my students and patients' parents, but then the responsibility for the qualification for vaccination and medical care of the vaccinated child was obvious and respected, and the issue of post-vaccination complications was not a taboo subject. I am convinced that nowadays, in the age of the Internet, bearing in mind parents' level of education, a fear-based message that demonises parents who demand voluntary vaccinations should not be brought into the public debate. I see the need here to think over the methods and techniques of health education by institutions and people responsible for public health in our country. However, these institutions and people have to be totally reliable.

\section{DISCLOSURE}

The author reports no conflict of interest.

Janusz Szymborski - graduate of the Wrocław Medical University (1969), paediatrician; professor of medical sciences (1996); director of the Institute of Mother and Child in Warsaw (1996-2001); adviser to the Children's Ombudsman (2003-2007); member of the Government Population Council (Rządowa Rada Ludnościowa) (since 2002); author and co-author of over 300 original scientific publications and 25 monographs. 